\title{
Attitude of Secondary School Teachers towards Value Pattern of Education In Relation to Gender, Teaching Effectiveness and Locality
}

\author{
Nimain Charan Mallik ${ }^{1}$, Jateendra Das ${ }^{2}$, Prasanta Mallik ${ }^{3}$ \\ ${ }^{1}$ Research Scholar, D.P. IASE, Berhampur University, Ganjam, Odisha \\ ${ }^{2}$ Guest Faculty, Department of Education, Ravenshaw University, Cuttack, Odisha \\ ${ }^{3}$ RGNF, Doctoral Fellow, Department of Education, Ravenshaw University, Cuttack, Odisha
}

\begin{abstract}
The investigator intended to examine the attitude of secondary school teachers towards value patterns of education in relation to Gender, Teaching effectiveness and Locality. The investigator adopted a descriptive survey method for the current study. The researcher selected by the random sampling method for data collection following four High schools of Cuttack District. Further, the investigator adopted an attitude scale developed by Rensis Likert for Data collection. For analysis of data, the researcher used the ' $t$ ' test. The findings showed no significant difference is found between the attitude of Male and Female Teachers on Value Education. Similarly, there is no significant difference exists between Rural and Urban teachers in their attitude towards Value Education.
\end{abstract}

KEYWORDS: Gender and Locality, Teaching effectiveness, Value Education.

\section{INTRODUCTION}

The twenty-first century inherited un-parallel multifaceted growth and development. Space was subjugated and human capabilities were challenged and even control by computers. The concept of the Computer world becomes visible. The citizens of the universe become neighbors. Human labor was reduced. In the view of our glorious tradition of poetry, tolerance, universal brotherhood and peaceful co-existence as contrasted with the present-day phenomenon of hypocrisy, corruption, dishonesty and inhuman attitudes. We are undoubtedly convinced that we face today the worst ever moral crisis. Crisis in character and loss of values are reflected in every sphere of life. Value refers to the things that we people appreciate and wish and assess them as desirable and notable assets. It may be a material object like houses, clothing and food and abstract ideas and qualities like truth, beauty, goodness, happiness and peace etc. India has a rich cultural heritage and has a number of ancient values which people have accepted as their common cultural heritage. Under the circumstances, the awaken of moral consciousness is the need of the hour. So in the curriculum value education should find a place for the development of human consciousness. According to New education policy 1986, re-adjustment of the curriculum is to be made to make it a forceful instrument for the improvement of moral and spiritual values. Value orientation of college students had no relationship to father's educational and occupational status, academic achievement and residential background, however, value orientation was associated with economic status with those who are lower-income being extra more spiritualism oriented whereas the higher income group more materialistic oriented. Value orientation was also associated to the size of the family. Generally, students from big families were extra more spiritualism oriented, and actually of those from small size family have more materialism oriented. Further, it has been seen female students were better adjusted than male students in all areas studied (Annamma, A.K. 1984). Another study showed male \& female prospective teachers equally allotted the highest importance to sympathy, submission and honesty. Women perspective teachers ranked helpfulness forgiveness, ambitions, and livingness more than their male counterparts, while male perspective teachers ranked independence, bravery, rationality, capability, authority and lofty than their female counterparts. The greater value to self-discipline and integrity and lowest significance to dialectics and potentiality given by female prospective teachers were not found to be affected by family vacations. Values like lovingness and helpfulness were characteristics preferences of the female group irrespective of family vacations. In the case of the male group, values were responsibility and capability. (Bhusan, A., 1983). Another research study revealed that male \& female teachers expressed a greater preference for the theoretical value and affiliation need. The teachers of both genders opined keen moral sense. Male teachers acquired many better points in the aesthetic, social and political values than female teachers. Urban male teachers were more moral than ural male teachers. Urban female teachers preferred social and economic values whereas rural female teachers 


\section{International Journal of Current Science Research and Review}

ISSN: 2581-8341

Volume 04 Issue 11 November 2021

DOI: 10.47191/ijcsrr/V4-i11-15, Impact Factor: 5.825

were religious, theoretical and aesthetic. (Kumari, p. 1981). Likewise, another study showed that male teachers secured a better point in social, political and aesthetic values. Male (Urban) teachers secured better points in the aesthetic, theoretical and social values. Urban male teachers expressed a high preference for achievement needs and the moral decision inventory. Generally, urban female educators, first preference are social and economic values while the case of rural female teachers indicates a high choice for aesthetic and religious values. Generally, urban female educators showed more batter average scores in the moral decision inventory. (Prabhawati, K.,1987).

\section{RATIONALE OF THE STUDY}

After reviewing the above literature, the investigator found that most of the studies showed that the country is faced with the problems such as - strikes, student's unrest, communal tensions and Black marketing. (Gangappa, 1974) suggests that the only remedy for all these evils is a national system of Education that is inspired by moral, spiritual and social values right from the nursery to the Research degree. To overcome the present value crisis, Rich (1968) suggest that, one can improve individuals in the belief that they, in turn, will improve society for this, there is a need to readdress the role of education employ, it for building upon the edifice of values, attitudes and moral standards. The programme of action on NPE 1986 contains that today there is an upsurge in favor of National integration and adherence to certain national values, concerns through introduction of a national core curriculum an insistence on observance of secular scientific and moral values, inculcation of an understanding of our composite culture with its rich diversity. Considering the above facts, it is concluded that value education is a must of the all-around growth and development of a child and it should be inculcated through the school curriculum. Hence the researcher is interested to conduct research on "Attitude of Secondary School Teachers towards Value Pattern of Education in Relation to Gender, Teaching effectiveness and Locality".

\section{OBJECTIVES OF THE STUDY}

1. To analyses the value pattern of secondary school teachers.

2. To compare the value pattern of male and female teachers.

3. To compare the value pattern of effective and ineffective teachers.

4. To compare the value pattern of Urban and Rural teachers.

\section{HYPOTHESES OF THE STUDY}

$\mathrm{Ho}_{1}$ : There is no significant difference in the value pattern of male and female teachers.

$\mathrm{Ho}_{2}$ : There is no significant difference in the value pattern of effective and ineffective teachers.

$\mathrm{Ho}_{3}$ : There is no significant difference in Rural-Urban teachers.

\section{METHODS OF THE STUDY}

The Investigator wants to survey the opinion of secondary school teachers towards value education. This is purely a descriptive one. The researcher used Likert's technique for the construction of the attitude scale. The scale statement is stated and the respondent is required to record the responses by circling a particular response given at the right-hand side of the statement. The response is usually expressed in terms of the 5-point scale i.e. Strongly Agree, (SA) Agree, (A) Undecided (UD), Disagree (D) and Strongly Disagree (SD). To score the alternative responses are credited as 5, 4, 3, 2, 1 respectively from favorable to unfavorable. Strongly agree with a favorable statement which could receive a score of 5 as would strongly disagree with an unfavorable statement. The sum of the item credits respondent the individuals to total score with established norms four High schools of Cuttack District were randomly selected to collect the Data, ers of each school are taken and a total of forty teachers are taken as the sample of the study. out of forty teachers, twenty are male and the rest twenty are female. 


\section{International Journal of Current Science Research and Review}

ISSN: 2581-8341

Volume 04 Issue 11 November 2021

DOI: 10.47191/ijesrr/V4-i11-15, Impact Factor: 5.825

IJCSRR@ 2021

Analysis and Interpretation of Data

Objective 1: To analyze the value pattern of secondary school teachers

\section{Value Pattern of Secondary School Teachers}

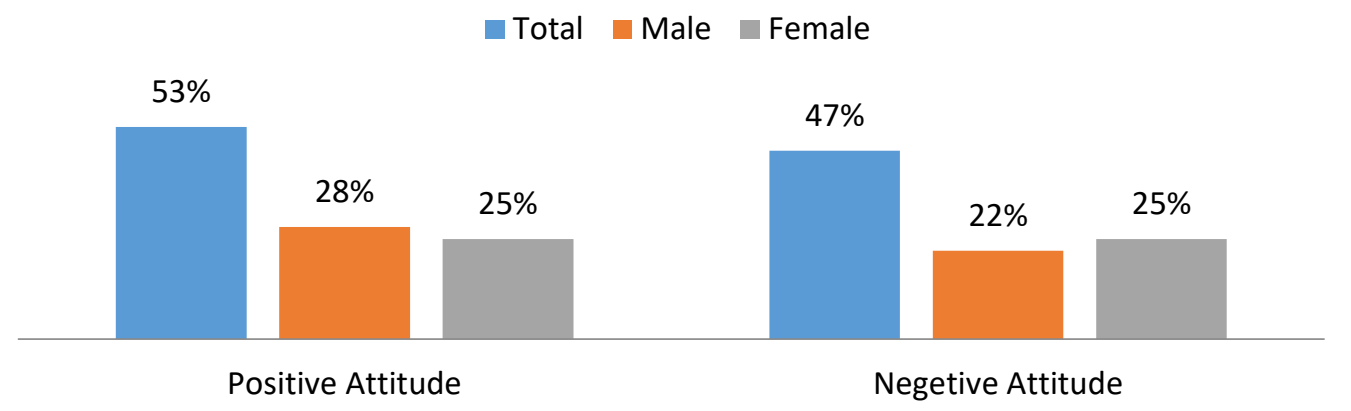

From the above diagram, it shows that $53 \%$ of the secondary school teachers have a positive attitude towards value education where $28 \%$ are male and $25 \%$ are female. It ensures that value education should be provided to the students at the secondary level which will develop values like morality, nationality, rationality and spirituality among the students. In contrast, there are $47 \%$ of secondary school teachers have a negative attitude towards value education at the secondary level.

Objective 2: To compare the value pattern of male and female teachers.

\begin{tabular}{|l|l|l|l|l|l|l|l|}
\hline Gender & N & Mean & S.D & df & 't' & 'P' Value & Remark \\
\hline Male & 20 & 56.75 & 15.596 & \multirow{2}{*}{38} & .295 & .770 & $\begin{array}{l}\text { Not } \\
\text { Significant }\end{array}$ \\
\cline { 1 - 4 } & 20 & 55.15 & 18.599 & & & & \\
\hline
\end{tabular}

Table No. 1 reveals that the calculated of value ' $\mathrm{t}$ ' with $\mathrm{df}(38)=.295$, $\mathrm{p}$-value $=.770(\mathrm{P}>.05)$ which was not significant at 0.05 level and 0.01 level of significance. Hence, the null hypothesis was accepted indicating that there was no significant difference in value pattern of secondary school teachers in relation to their gender.

Objective 3: To compare the value pattern of effective and ineffective teachers.

\begin{tabular}{|l|l|l|l|l|l|l|l|}
\hline Gender & $\mathbf{N}$ & Mean & S.D & df & ' $\mathbf{t}$ ' & 'P' Value & Remark \\
\cline { 1 - 6 } Male & 22 & 62.91 & 15.844 & \multirow{2}{*}{38} & 3.188 & .003 & \multirow{2}{*}{ Significant } \\
\cline { 1 - 3 } Female & 18 & 47.44 & 14.513 & & & & \\
\hline
\end{tabular}

Table No. 2 reveals that the calculated of value ' $\mathrm{t}$ ' with $\mathrm{df}(38)=3.188$, $\mathrm{p}$-value $=.003(\mathrm{P}>.05)$ which was significant at 0.05 level and 0.01 level of significance. Hence, the null hypothesis was rejected

Objective 4: To compare the value pattern of Urban and Rural teachers. Indicating that there was significant difference in value pattern of secondary school teachers in relation to their teaching effectiveness.

\begin{tabular}{|c|c|c|c|c|c|c|c|}
\hline Gender & $\mathbf{N}$ & Mean & S.D & df & ' $t$ ' & 'P' Value & Remark \\
\hline Male & 20 & 57.95 & 16.353 & \multirow{2}{*}{38} & \multirow{2}{*}{.741} & \multirow[b]{2}{*}{.463} & \multirow{2}{*}{$\begin{array}{l}\text { Not } \\
\text { significant }\end{array}$} \\
\hline Female & 20 & 53.95 & 17.739 & & & & \\
\hline
\end{tabular}




\section{International Journal of Current Science Research and Review}

ISSN: 2581-8341

Volume 04 Issue 11 November 2021

DOI: 10.47191/ijesrr/V4-i11-15, Impact Factor: 5.825

IJCSRR@ 2021

WwW.ijcsrr.org

Table No. 3 reveals that the calculated of value ' $\mathrm{t}$ ' with $\mathrm{df}(38)=.741$, $\mathrm{p}$-value $=.463(\mathrm{P}>.05)$ which was not significant at 0.05 level and 0.01 level of significance. Hence, the null hypothesis was accepted indicating that there was no significant difference in value pattern of secondary school teachers in relation to their locality.

\section{MAJOR FINDINGS}

It is found that $53 \%$ of the secondary school teachers have a positive attitude towards value education where $28 \%$ are male and $25 \%$ are female. It ensures that value education should be provided to the students at the secondary level which will develop values like morality, nationality, rationality and spirituality among the students. In contrast, there are $47 \%$ of secondary school teachers have a negative attitude towards value education at the secondary level. Further, it indicates that there was no significant difference in the value pattern of secondary school teachers in relation to their gender \& Locality. But so far the Teaching Effectiveness, indicates that there was a significant difference in the value pattern of secondary school teachers in relation to their teaching effectiveness.

\section{THE IMPLICATION OF THE STUDY}

On the basis of the findings of the study the educational implications are:

1. Value education needs to be imparted to the students. For this orientation and refresher courses are to be organized for teachers.

2. Value education should be generated through various school subjects rather than introducing it as a separate subject.

3. Value education can better be imparted through organizing different co-curricular activities like working assembly etc.

\section{REFERENCES}

1. Aggarwal, J.C. (1996) Research in Education- An introduction, Arya Book Depot, New Delhi.

2. Best, W.J.\& Kahn, J.V. (1988) Prentice Hall of India, Pvt. Ltd. New Delhi, (1988).

3. Bhuni Kutsu, (1992) A study of the values of college students in Nagaland in relation to their Self-concept, Ph.D., Education. The fifth survey of educational Research 1998-02, NCERT, New Delhi.

4. Buch, M.B. (Ed.) (1974) A survey of Research in Education, Case, M.S. University of Baroda.

5. Buch, M.B. (Ed) (1979) Second survey of Research in education, society for Educational Research and Development, Baroda.

6. Coleman, (1971) In I. C. Sinha (Education) Effectiveness of Value clarifying strategy in value orientation of B.Ed. students, SCERT, NEW Delhi., 1986.

7. Frankes, J. R. (1977) How to teach about values: An analytical approach, New Jersey prentice Hall, Inc. England Cliffs.

8. Goyal, B.R. (1979) Document of Social, Moral \& Spiritual values in Education, New Delhi, NCERT.

9. Kothari, D.S. (1964-66) Education \& Values, in Report of the Oriental Course come work upon Education in Human Values, New Delhi, Municipal Corporation of Delhi, Department of Education.

10. Mathur, V. S. (1983) "Value Based Education” Journal of Indian Education, 8 (5), 21-24, January.

11. Morrill, R.L. (1980) Teaching Values in Colleges: San Francisco; Joseey Bass Publishers.

12. Ramji, M. T. (1973) Value Oriented School Education, New Delhi, NCERT.

13. Singh, N. (1992) Values of High and Low Achievers: A Social-Psychological Study, Indian Psychological Review.

14. Shukla, R. S. (1983) Education of Human Values at Primary Level, Trends in Education.

Cite this Article: Nimain Charan Mallik, Jateendra Das, Prasanta Mallik (2021). Attitude of Secondary School Teachers towards Value Pattern of Education In Relation to Gender, Teaching Effectiveness and Locality. International Journal of Current Science Research and Review, 4(11), 1592-1595 